\title{
EKSISTENSI KOSA KATA BAHASA MINANGKABAU OLEH PENUTUR TUA DAN PENUTUR MUDA
}

\author{
Werni \\ Fakultas Ilmu Budaya Universitas Andalas
}

\begin{abstract}
This article describes words that have changed the Minangkabau language vocabulary by Old Speakers and Young Speakers in Kanagarian Gunuang Rajo and the causes of these changes.

The method used consists of three stages, the provision of data, the data analysis stage, and the stage of presenting the results of data analysis. The methods and techniques used in the data provision stage are competent methods and referring methods. In the skillful method used proficient techniques, fishing techniques, note-taking techniques, and recording techniques, while the listening method was used tapping technique, then continued with several techniques, namely SLC technique and SBLC technique. In data analysis used referential and translational matching methods with basic techniques, namely PUP techniques. The follow-up technique is the HBB technique. The results of data analysis and classification found two forms of changes in vocabulary usage in Kanagarian Gunuang Rajo, namely 1) Words that are lost or not used anymore caused by internal and external factors. Internal factors, namely: homonymic conflict. External factors, namely: social aspects, age, education and foreign languages, 2) The emergence of new vocabulary found only in the form of new words formed from outside Kanagarian Gunuang Rajo.
\end{abstract}

Keywords: Change, vocabulary, factors, old speakers, speakers

\section{PENGANTAR}

Bahasa adalah salah satu jendela untuk melihat dunia lebih luas. Chaer (Chaer, 2003) mengatakan bahwa bahasa adalah satu-satunya milik manusia yang tidak pernah lepas dari segala kegiatan dan gerak manusia. Manusia sebagai makhluk yang berbudaya dan bermasyarakat menggunakan bahasa dalam setiap kegiatannya. Kegiatan manusia selalu berubah-ubah maka bahasa pun juga ikut berubah. Selain itu, berbagai pengaruh dari luar atau dalam dapat pula membuat bahasa menjadi berubah. Hal ini membuat bahasa bersifat dinamis.

Bahasa dapat berubah berdasarkan tuturannya unsur seperti, fonologi, morfologi, sintaksis, semantik, dan leksikal (kosa kata). Perubahan bahasa terjadi secara perlahan-lahan. Perubahan bahasa sering kali tidak disadari oleh penuturnya. Perubahan bahasa tidak dapat diamati sebab perubahan sudah menjadi sifat hakiki bahasa, berlangsung dalam waktu yang lama sehingga tidak mungkin diobservasi oleh seseorang yang mempunyai waktu yang relatif terbatas. Namun, yang dapat diketahui adalah bukti adanya perubahan bahasa itu (Chaer, 2010).

Perubahan bahasa merupakan salah satu aspek penting untuk diteliti. Perubahan bahasa dapat menuju pada dua arah, yaitu menjadi lebih luas daerah pakainya atau malah dapat lenyap. Salah satu hal yang menarik dalam penelitian sebuah bahasa adalah perubahan bahasa yang disebabkan oleh pengguna bahasa berdasarkan faktor usia, yaitu membandingkan proses perubahan bahasa pada dua generasi yang berbeda (kelompok usia). Proses perubahan bahasa dapat dilihat dari pengguna bahasa dari generasi usia tua dan generasi usia muda sehingga dapat mengetahui perubahan bahasa pada dua kelompok usia yang mewakili masing-masing generasi. Ketika satu generasi berbicara dengan bahasa yang berbeda dengan generasi sebelumnya maka hal ini merupakan 


\section{Jurnal Elektronik WACANA ETNIK - Vol 6 No 2 Oktober 2017, (97 - 110) \\ p ISSN 2089-8746, e ISSN 2302-7142}

salah satu bentuk perubahan bahasa berdasarkan faktor usia pengguna bahasa. Sehubungan dengan itu, penulis meneliti perubahan bahasa yang terjadi oleh penutur tua dan penutur muda.

Penulis menggunakan ketetapan Depkes RI tahun 2009 sebagai landasan untuk mengklasifikasikan kelompok usia tua dan kelompok usia muda, yakni usia 17-30 (usia muda) dan penutur usia 50-65 (usia tua), masing-masing sampel diambil tiga orang informan usia tua dan informan usia muda. Informan pertama menjadi informan utama dan dua informan lainya menjadi informan pendamping. Untuk penutur usia tua selain usia kriteria lainnya yaitu informan penduduk asli menetap di sana dan jarang merantau dalam waktu yang lama, tidak pikun, memiliki alat ucap yang sempurna dan lengkap. Informan usia muda diambil usia 17-30 tahun karena usia tersebut adalah masa mengalami perubahan dalam bertutur. Usia ini merupakan usia yang cukup banyak meniru dalam berbahasa atau bertutur sehingga memungkinkan banyak kosa kata yang digunakan oleh penutur tua tidak di mengerti oleh penutur muda.

Selain faktor usia pengguna bahasa, perubahan bahasa dapat juga terjadi oleh berbagai faktor. Faktorfaktor tersebut antara lain faktor yang berasal dari pengguna bahasa itu sendiri dan faktor lingkungan pengguna bahasa. Ketika dua kosa kata digunakan secara berdampingan dengan makna yang sama maka pengguna bahasa akan cenderung memilih salah satu kosa kata untuk digunakan. Akibatnya, kosa kata yang tidak terpilih akan terlupakan dan akhirnya hilang. Hal ini merupakan faktor perubahan bahasa karena penutur bahasa itu sendiri. Selanjutnya, faktor perubahan bahasa yang disebabkan lingkungan pengguna bahasa dapat terjadi karena kondisi sosial. Kondisi sosial yang dimaksud adalah usia, pendidikan, pekerjaan, keadaan sosial ekonomi, jenis kelamin, dan lainnya.

Masyarakat Indonesia umumnya termasuk masyarakat dwibahasa/multibahasa. Hal ini disebut demikian karena dalam kehidupan sehari-hari masyarakat Indonesia, terutama masyarakat perkotaan, dapat menggunakan lebih dari satu bahasa (daerah dan Indonesia). Dalam masyarakat yang multibahasa persaingan bahasa merupakan fenomena yang sering terjadi sebagai akibat kontak. Persaingan yang terjadi yaitu antara bahasa daerah, bahasa nasional, dan bahasa asing. Oleh karena itu, kekhawatiran akan punahnya bahasa daerah semakin beralasan. Gejala kepunahan tersebut ditandai secara awal oleh merosotnya jumlah penutur karena adanya persaingan bahasa tersebut (desakan bahasa Indonesia dan bahasa asing) dan semakin kurangnya loyalitas penutur terhadap pemakaian bahasa daerah sebagai bahasa ibu (Sobarna, 2007).

Kekurangmampuan generasi muda dalam menggunakan bahasa daerah, tidak terlepas dari pengaruh semakin kuatnya eksistensi bahasa nasional. Bahasa Indonesia yang semula hanya digunakan dalam situasi resmi, kini menyeruak pada situasi tidak resmi, termasuk penggunaannya di lingkungan keluarga. Di sisi lain, Penilaian ini didasarkan pada fakta bahwa terdapat kecenderungan kuat penggunaan bahasa Indonesia dalam berbagai ranah kehidupan telah terdesak atau tergeser oleh bahasa asing. Kecenderungan seperti ini antara lain dapat dilihat pada berbagai media iklan, kain rentang, baliho, nama-nama toko, nama-nama hotel, nama-nama pusat perbelanjaan, nama-nama perumahan, nama-nama salon, nama-nama usaha jasa pencucian pakaian, nama-nama usaha jahitmenjahit pakaian, nama-nama usaha jasa boga, nama-nama pusat kebugaran, nama-nama bank, nama-nama stasiun televisi swasta, dan lain-lain.

Kecenderungan menggunakan bahasa asing ini sudah merambah ke kota-kota kecil setingkat kabupaten, tidak hanya pada masyarakat kelas menengah ke atas, tetapi juga masyarakat kelas menengah ke bawah. Penggunaan bahasa asing yang kurang pada tempatnya tampaknya terjadi juga pada lembaga pendidikan, media 


\section{Jurnal Elektronik WACANA ETNIK - Vol 6 No 2 Oktober 2017, (97 - 110)}

p ISSN 2089-8746, e ISSN 2302-7142

massa, baik cetak maupun elektronik, atau masyarakat pada umumnya. Di lembaga pendidikan, misalnya, kita sering mendengar istilah Play Group, Full Day School, Baby Smile School, passing grade, academic, excellent, pilot project, dan lain-lain. Di media cetak tidak sulit kita menemukan kata-kata asing yang bertebaran (Khasanah, Laksmita, Tilman, \& Rizky, 2015).

Hal inilah yang terjadi pada masyarakat di Kenagarian Gunuang Rajo. Berdasarkan pengamatan awal terdapat beberapa kosa kata yang dituturkan oleh penutur usia tua yang tidak seutuhnya dapat dimengerti oleh penutur usia muda. Dengan kata lain, terdapat dua kosa kata yang berbeda antara penutur usia tua dengan penutur usia muda terhadap makna kata yang sama. Hal ini merupakan salah satu bentuk perubahan penggunaan kosa kata.

\section{KERANGKA PEMIKIRAN DAN METODOLOGI}

Sosiolinguistik adalah ilmu yang mempelajari bahasa dan erat kaitannya dengan penggunaan bahasa dalam masyarakat. Dengan kata lain, sosiolinguistik mempelajari hubungan bahasa dengan kegiatan-kegiatan atau aspek-aspek kemasyarakatan (Chaer, 2010).

Hal senada juga dikemukakan oleh Kridalaksana (Kridalaksana, 2008) bahwa sosiolinguistik adalah cabang linguistik yang mempelajari hubungan dan saling pengaruh antara perilaku bahasa dan perilaku sosial. Dari beberapa pengertian sosiolinguistik yang dikemukakan oleh ahli bahasa tersebut dapat disimpulkan bahwa sosiolinguistik adalah salah satu cabang dari linguistik yang mengkaji hubungan bahasa dengan faktor sosial dari masyarakat tutur dalam berinteraksi.

Salah satu pembahasan dalam sosiolinguistik adalah tentang perubahan, pergeseran, dan pemertahanan bahasa. Perubahan bahasa menyangkut persoalan bahasa sebagai kode, sesuai dengan sifatnya yang dinamis, dan sebagai akibat persentuhan dengan kode-kode lain. Perubahan bahasa lazim diartikan sebagai adanya perubahan kaidah, entah kaidahnya itu direvisi, kaidahnya menghilang atau munculnya kaidah baru, dan semua itu terjadi pada semua tataran linguistik; fonologi, morfologi, sintaksis, semantik maupun leksikon (kosa kata).

Membahas tentang perubahan bahasa, pertanyaan pertama yang muncul dalam pikiran penulis, sama dengan pernyataan yang dipaparkan oleh Wardhaught (dalam Chaer, 2010) yakni apakah perubahan penggunaan bahasa itu dapat diamati atau diobservasi. Terjadinya perubahan penggunaan bahasa tentunya tidak dapat diamati sebab perubahan itu sudah menjadi sifat hakikinya bahasa. Selain itu, terjadinya perubahan bahasa berlangsung dalam waktu yang relatif lama sehingga tidak mungkin bisa diobservasi oleh seseorang yang mempunyai waktu relatif terbatas. Namun, hal yang dapat diketahui adalah bukti adanya perubahan bahasa itu.

Perubahan penggunaan bahasa yang paling mudah terlihat adalah pada bidang kosa kata. Chaer (Chaer, 2010) menyatakan bahwa perubahan kosa kata dapat terjadi seperti, hilangnya kosa kata tertentu, timbulnya kosa kata baru, dan hilangnya kosa kata lama. Selain itu, perubahan pelafalan dapat memunculkan berbagai jenis variasi. Jadi, perubahan penggunaan kosa kata dapat diketahui dari tumbuhnya kosa kata baru, bertahannya kosa kata lama dengan perubahan bunyi dan pelafalan, dan hilangnya kosa kata lama akibat tidak digunakan lagi dengan perubahan bunyi dan pelafalan, serta hilangnya kosa kata lama akibat tidak digunakan lagi oleh penuturnya. Perubahan kosa kata terjadi akibat dari hilang atau tidak dipakai lagi kosa kata lama, serta perubahan makna dan 


\section{Jurnal Elektronik WACANA ETNIK - Vol 6 No 2 Oktober 2017, (97 - 110) \\ p ISSN 2089-8746, e ISSN 2302-7142}

munculnya kosa kata baru. Hilangnya kosa kata lama disebabkan oleh dua faktor, yaitu faktor internal dan eksternal.

Menurut Usman (Usman, 1979), faktor internal merupakan perubahan yang terjadi (dalam bahasa) itu sendiri, sedangkan faktor eksternal terjadi akibat perubahan dari (luar bahasa) itu sendiri seperti (1) pertentangan homonimis yaitu kata-kata yang memiliki bentuk yang sama tapi maknanya berbeda, kemudian dalam perkembangannya, salah satu makna kata tersebut hilang jika kata tersebut menimbulkan keraguan; (2) penghilangan bunyi pada awal kata, tengah kata, dan akhir kata; (3) pemendekan kata, yaitu penanggalan satu atau beberapa dari bagian dari sebuah kata sehingga terjadi bentuk baru. Sementara itu, faktor eksternal yang mempengaruhinya seperti (1) segi kemasyarakatan yang dihubungkan dengan kebiasaan (kehidupan sosial) masyarakatnya; (2) Sejarahnya yang dapat berupa sejarah sebuah kata, maupun tidak ada lagi rujukan kata tersebut.

Selain itu, perubahan makna kata dapat terjadi karena berbagai cara seperti, penyempitan makna yaitu kata yang ada sekarang menyempit artinya. Perluasan makna, yaitu kata yang sekarang meluas maknanya, dan juga karena pemindahan makna. Selanjutnya, munculnya kata baru. Cara pembentukan kata baru ada dua, yaitu (1) kata-kata yang dibentuk dalam bahasa itu sendiri; (2) kata-kata yang dibentuk dari bahasa lain.

Menurut Chaer (Chaer, 2010), sosiolek atau dialek sosial, yakni variasi bahasa yang berkenaan dengan status, golongan, dan kelas sosial para penuturnya. Dengan kata lain, variasi bahasa yang berkenaan dengan semua masalah pribadi penuturnya seperti, usia, dapat dilihat dari perbedaan variasi bahasa yang digunakan oleh anakanak, remaja, dewasa, dan para lansia. Perbedaan variasi ini berkenaan juga dengan bidang penggunaan kosa kata. Peneliti juga berpedoman pada faktor-faktor tersebut karena faktor-faktor tersebut juga menyebabkan perubahan kosa kata. Semenjak kualitas pendidikan di setiap daerah telah ditingkatkan (termasuk di Kenagarian Gunuang Rajo) bahasa pun ikut berkembang. Bahasa yang digunakan di lembaga pendidikan adalah bahasa formal, yaitu bahasa Indonesia, turut mempengaruhi terjadinya perubahan kosa kata.

Sebagian perantau dari Kenagarian Gunuang Rajo, secara informal mempelajari bahasa asli tempat yang baru datangi hingga paham dan menguasai bahasa daerah yang mereka tempati agar bisa berkomunikasi dengan bahasa yang bersangkutan. Kosa kata masyarakat perantau akan terpengaruh oleh kosa kata bahasa daerah yang didatanginya. Kosa kata inilah yang dibawa pulang ke Kenagarian Gunuang Rajo dan secara tidak sadar mempengaruhi kosa kata asli masyarakat Kenagarian Gunuang Rajo Jelaslah bahwa kedua situasi di atas mempengaruhi terhadap hilangnya sebagian kosa kata bahasa Minangkabau di Kenagarian Gunuang Rajo.

Bahasa mempunyai fungsi dan prestise yang berbeda. Penutur suatu bahasa akan memilih kata-kata yang dianggap bergengsi untuk diucapkan. Guna mengimbangi penutur muda dalam percakapan sehari-hari, penutur tua cenderung memakai kosa kata yang digunakan oleh masyarakat umum sehingga lebih mudah dimengerti oleh semua golongan masyarakat. Perubahan kosa kata yang berwujud hilangnya atau tidak digunakannya lagi kata lama dapat juga dipengaruhi oleh frekuensi pemakaian kata-kata tersebut. Semakin jarang kosa kata dipakai oleh penutur bahasa Minangkabau di Kenagarian Gunuang Rajo, maka semakin besar kemungkinan kosa kata tersebut akan hilang, dan begitu juga sebaliknya. Pergeseran bahasa merupakan masalah penggunaan bahasa oleh seorang penutur atau sekelompok penutur, yang terjadi sebagai akibat dari perpindahan dari masyarakat tutur ke masyarakat tutur. 
Jika seorang penutur pindah ke tempat lain yang memiliki bahasa berbeda dengan tempat asalnya maka akan mengakibatkan perubahan bahasa (perubahan kosa katanya). Mereka akan terpengaruh dengan bahasa tempat mereka merantau sebab ketika menjadi pendatang, mereka harus menyesuaikan diri dengan bahasa yang digunakan oleh penutur sekitar. Mereka "meninggalkan” bahasanya sendiri lalu menggunakan bahasa penduduk setempat. Ketika si perantau pulang ke tempat asalnya, mereka membawa bahasa dan kosa kata yang telah terpengaruh oleh kosa kata bahasa yang didatanginya.

\section{TEMUAN DAN PEMBAHASAN}

\section{KATA YANG HILANG ATAU TIDAK DIPAKAI OLEH PENUTUR DI KANAGARIAN GUNUANG RAJO}

Adanya kecenderungan penutur muda mengabaikan kata lama dan lebih suka menggunakan kata baru, dapat terjadi karena yang mereka dapat atau yang mereka dengar, serta tidak adanya lagi suatu benda atau hal yang merujuk pada kata lama tersebut. Setelah dilakukan klasifikasi data ditemukan adanya kata-kata yang hilang dan tidak dipakai lagi yang disebabkan oleh faktor internal dan eksternal. Berikut dipaparkan satu persatu contoh kata yang mengalami perubahan serta faktor yang mempengaruhinya.

\section{FAKTOR INTERNAL}

Setelah dilakukan klasifikasi data ditemukan bahwa, hilang atau tidak dipakainya sebagian kosa kata lama oleh penutur tua dan penutur muda KGR disebabkan oleh faktor internal. Perubahan yang disebabkan oleh faktor internal meliputi: pertentangan homonimis, penghilangan bunyi, dan pemendekan kata. Kata-kata yang hilang atau tidak dipakai lagi oleh penutur tua dan penutur muda KGR dapat dilihat pada data berikut, dengan klasifikasi yang berdasarkan pada faktor penyebabnya.

Adanya kata-kata yang memiliki bentuk sama tetapi makna berbeda, membuat penutur tua dan penutur muda KGR meninggalkan salah satu kata dan menggantinya dengan kata yang lain. Ini dilakukan untuk menghindari keraguan makna kata dari kata yang homonimis.

Penutur muda

(1) : Toloang ambiak-an anduak tu ciek!

: Tolong ambilkan handuk itu satu!

: 'Tolong ambilkan handuk!'

(2) : Oi, bilo Ang bayia utang Ang?

: Oi, kapan kamu bayar utang Kamu?

: 'Hei, kapan Kamu (laki-laki) bayar utang?'

Penutur tua

(1) : Toloang ambiak an anduak tu ciek!

: Tolong ambilkan handuk itu satu!

: 'Tolong ambilkan handuk!'

(2) : Oi, bilo Ang bayia anduak Ang?

: Oi, kapan kamu bayar utang Kamu?

: Hei, kapan Kamu (laki-laki) bayar utang?

Penutur tua mengungkapkan bahwa ketika masih berusia muda, mereka menggunakan kata anduak untuk merujuk pada makna 'handuk' dan juga untuk makna 'utang'. Namun, sekarang penutur tua cenderung menggunakan kata anduak hanya mengacu pada makna 'handuk'. Hal ini mengakibatkan penutur muda hanya 


\section{Jurnal Elektronik WACANA ETNIK - Vol 6 No 2 Oktober 2017, (97 - 110)}

p ISSN 2089-8746, e ISSN 2302-7142

mengenal kata anduak untuk makna 'handuk'. Selanjutnya, kata anduak hanya merujuk pada makna 'utang' saja mulai ditinggalkan dan lama kelamaan kata yang jarang digunakan berpotensi hilang dengan sendirinya.

\section{FAKTOR EKSTERNAL}

Hilangnya kata karena faktor eksternal berhubungan erat dengan sejarah dan segi kemasyarakatan dari penutur tua dan penutur muda KGR itu sendiri. Di KGR terdapat kosa kata yang dahulu pernah dipakai. Sekarang hilang atau tidak dipakai lagi baik oleh penutur tua maupun oleh penutur muda.

Segi kemasyarakatan turut mempengaruhi perubahan kosa kata penutur tua dan penutur muda KGR. Masyarakat Gunuang Rajo cenderung melakukan pemilihan terhadap pemakaian dua kata yang bersinonim. Hal ini menyebabkan berkurangnya frekuensi pemakaian salah satu kata sehingga kata yang berfrekuensi rendah menjadi hilang atau tidak dipakai lagi. Selain kebiasaan tersebut, masyarakat juga melakukan penyamaan penamaan pada dua rujukan kata. Masyarakat tidak lagi melakukan pembedaan penamaan terhadap kedua rujukan tersebut sehingga salah satu kata atau keduanya menjadi hilang karena digantikan oleh kata baru. Contoh katakata yang hilang atau tidak dipakai lagi yang dipengaruhi oleh segi kemasyarakatan terdapat pada data-data berikut ini.

Penutur muda

: Amak pai manggiliang padi ka eler Kelok

: Ibu pergi menggiling padi ke eler Kelok

: 'Ibu pergi menggiling padi ke Heler Kelok'

Penutur tua

: Amak pai manumbuak padi ka kincia lakang

: Ibu pergi menggiling padi ke kincia belakang

: 'Ibu pergi menggiling padi ke kincir belakang'

Kosa kata kincia hanya diketahui oleh penutur tua. Sementara bagi penutur muda, untuk merujuk pada kata ,heler ${ }^{\text {ee }}$ mereka menggunakan kata eler. Kincia adalah tempat orang tua zaman dahulu untuk menggiling padi menjadi beras. Eler juga tempat menggiling padi menjadi beras. Perbedaan antara eler dan kincia adalah eler menggunakan mesin sedangkan kincia menggunakan kekuatan air.

Sesekali penutur muda pernah mendengar kata kincia. Akan tetapi, mereka tidak mengetahui apa artinya, apalagi mempergunakannya dalam percakapan sehari-hari. Faktor yang menyebabkan kata kincia hilang dan tidak digunakan lagi adalah karena tidak ada lagi alat tersebut digunakan oleh masyarakat Nagari Gunuang Rajo. Sekarang masyarakat menggiling padi tidak lagi menggunakan kincia tetapi, menggunakan jasa eler. Menurut mereka eler selain menghemat waktu eler lebih cepat kerjanya dibandingkan kincia.

Penutur muda

: Tanjudin, lah bacakak lo malam tadi jo Si Kalek

: Tanjudin, sudah bacakak pula malam tadi dengan si Kalek

: 'Tanjudin dan Kalek berkelahi tadi malam'

Penutur tua

: Tanjudin, lah babiteh lo malam tadi jo Si Kalek

: Tanjudin, sudah babiteh pula malam tadi dengan si Kalek

: 'Tanjudin dan Kalek berkelahi tadi malam'

Tuturan di atas memiliki makna yang sama. Dua bentuk ini pada dasarnya merupakan bentuk yang mengalami perubahan kata. Bentuk pertama, babiteh merupakan bentuk awal yang digunakan penutur tua. Sementara bentuk kata kedua, bacakak merupakan bentuk yang digunakan oleh penutur muda sekarang. Penutur 


\section{Jurnal Elektronik WACANA ETNIK - Vol 6 No 2 Oktober 2017, (97 - 110) \\ p ISSN 2089-8746, e ISSN 2302-7142}

muda sudah tidak mengenal lagi kata babiteh yang merujuk pada makna perkelahian. Penutur muda sekarang lebih mengerti dengan kata bacakak untuk makna berkelahi.

Faktor yang menyebabkan hilangnya kata babiteh dan digantikan oleh kata bacakak karena masyarakat lebih sering menggunakan kata bacakak dibandingkan dengan kata bebiteh. Hal ini mengakibatkan lama kelamaan kata babiteh hilang dengan sendirinya. Kata ini hanya akan dituturkan kembali oleh penutur tua pada waktu dan kondisi tertentu saja. Misalnya, saat penulis mewawancarai para informan penutur usia tua dan menanyakan contoh kata-kata yang tidak dipakai lagi oleh masyarakat Gunuang Rajo.

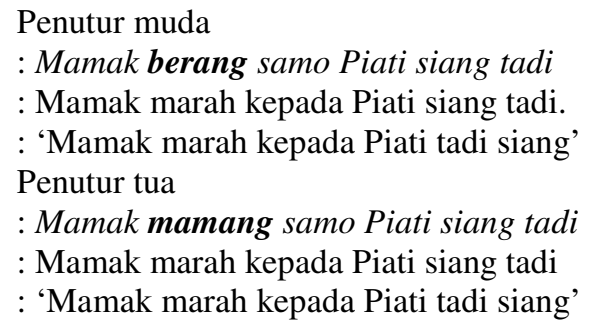

Pada tuturan di atas, terlihat bahwa penutur muda menggunakan kata berang yang merujuk pada makna 'marah'. Penutur tua, selain menggunakan kata berang, sesekali juga menggunakan kata mamang. Kedua kata tersebut memiliki makna yang sama yaitu 'marah'. Penutur tua mengetahui dan mengerti kata mamang hanya saja mereka lebih cenderung menggunakan kata berang dalam percakapan sehari-hari. Inilah yang menyebabkan ada sebagian dari penutur lupa kata tersebut, sehingga ketika diminta menyebutkan makna 'marah' ke dalam tuturan asli Gunuang Rajo, penutur tua pada mulanya hanya mengingat kata berang.

Selain itu, keinginan untuk dapat berinteraksi dengan baik dengan penutur muda. Maka penutur tua merasa perlu mengimbangi kosa kata yang dipergunakan oleh penutur muda penutur tua pun ikut menggunakan kosa kata mamang menjadi kosa kata berang. Inilah yang menyebabkan penutur tua lebih cenderung menggunakan kata berang dalam percakapan sehari-hari sehingga penutur tua pun mulai ikut melupakan kata mamang.

Penutur muda

: Awak lai gagah tapi gata

: 3TG ganteng tetapi genit.

: 'Kamu ganteng tetapi genit'

Penutur tua

: Awak lai gagah tapi pancaluang

: 3TG ganteng tetapi genit

: 'Kamu ganteng tetapi genit'

Pada data di atas, terlihat jelas perbedaan penggunaan antara penutur muda dan penutur tua. Kata pancaluang dituturkan oleh penutur tua Nagari Gunuang Rajo ketika penulis menanyai kata lama yang merujuk pada makna genit. Namun, setelah wawancara, mereka kembali mengabaikan penggunaan kata lama tersebut. Oleh karena jarangnya kata pancaluang digunakan dalam percakapan sehari-hari, hal ini menyebabkan penutur muda tidak lagi mengetahui kata ini. Tambahan lagi, penutur tua pun mulai meninggalkan kata pancaluang. Hal ini akan menjadikan kata pancaluang menjadi hilang dalam penggunaan bahasa penutur muda dan penutur tua di Kenagarian Gunuang Rajo. 
Penutur muda

: Bilo hari manunai calon minantu wak tu?

: Kapan hari meminang calon menantu kita itu?

: 'Kapan kita meminang calon menantu itu?'

Penutur tua

: Bilo hari maetek calon minantu wak tu?

: Kapan hari meminang calon menantu kita itu?

: 'Kapan kita meminang calon menantu itu?'

Berdasarkan data di atas terlihat jelas perbedaan penggunaan kata antara penutur muda dan penutur tua. Kata manunai dituturkan oleh penutur usia muda di Kenagarian Gunuang Rajo. Sementara penutur usia tua menggunakan kata maetek. Kata manunai dan maetek memiliki makna yang sama yakni 'meminang'. Peristiwa tuturan tersebut terjadi saat seorang penutur ingin 'meminang' seseorang yang akan menjadi menantu mereka. Dalam tuturan di atas, seorang penutur bertanya kepada penutur lain, hari apa mereka akan 'meminang' calon menantu mereka.

Saat ini, kata maetek sudah tidak digunakan lagi. Hal ini terbukti saat penulis melakukan wawancara. Ketika penulis mengajukan pertanyaan kepada penutur muda tentang kata yang merujuk pada makna 'meminang' dengan menggunakan kata maetek, mereka sama sekali tidak mengerti dengan pertanyaan yang penulis ajukan. Setelah itu, penulis mengubah pertanyaan penulis dan mengganti kata maetek menjadi kata manunai, barulah penutur muda mengerti dengan pertanyaan yang penulis ajukan. Di sini terlihat bahwa kata maetek memang sudah punah dan digantikan oleh kata manunai.

Penutur muda

: Lai kau kuncang karambia tu lu?

: Ada 2TG guncang kelapa itu dahulu?

: 'Adakah kamu (perempuan) guncang kelapa itu terlebih dahulu?'

Penutur tua

: Lai kau kucak karambia tu lu?

: Ada 2TG guncang kelapa itu dahulu?

: 'Adakah kamu (perempuan) guncang kelapa itu terlebih dahulu?'

Penutur bahasa Minangkabau di Kenagarian Gunuang Rajo semua golongan usia, memakai kata kuncang untuk merujuk pada makna 'guncang'. Namun, sebagian dari penutur tua adakalanya sesekali (seperti saat wawancara) memakai kata kucak. Kata kucak saat ini tidak lagi dipakai oleh penutur muda. Ini akibat dari rendahnya frekuensi penggunaan kata kucak rendah dalam percakapan yang dilakukan sehari-hari.

Penutur muda

: Ibuk gurunyo pamberang.

: Ibu gurunya pemarah.

: 'Ibu gurunya pemarah'

Penutur tua

: Ibuk gurunyo pamburansiang.

: Ibu gurunya pemarah.

: 'Ibu gurunya pemarah'

Kata pamburansiang sudah tidak digunakan lagi. Jika ada yang menuturkan kata tersebut kepada penutur muda, mereka sama sekali tidak akan menghiraukan kata tersebut. Jika ada yang mengucapkan kata pamberang 
maka mereka akan langsung mengerti dan mamahami kata tersebut. Kedua kata tersebut, yakni kata pamburansiang dan kata pamberang memiliki makna yang sama, yakni pemarah. Akan tetapi, kata pamburansiang saat ini sudah tidak digunakan lagi. Kata ini akan muncul saat situasi dan kondisi tertentu seperti, saat penulis melakukan wawancara kepada penutur tua. Tanpa mereka sadari, mereka mengucapkan kata tersebut.

Hilangnya kata pamburansiang terjadi karena pengaruh faktor eksternal dari segi kemasyarakatan yang berhubungan dengan masyarakatnya. Masyarakat Kenagarian Gunuang Rajo mulai jarang menggunakan kata pamburansiang dibandingkan dengan kata pamberang. Jika ini terus dibiarkan bisa berpotensi kata pamburansiang akan hilang seiring berkembangnya zaman.

Penutur muda

: Kaki amak sapiradan aa.

: Kaki ibu kesemutan KF.

: 'Kaki ibu kesemutan'

Penutur tua

: Kaki amak ngarijan aa.

: Kaki ibu kesemutan KF.

: 'Kaki ibu kesemutan'

Penutur muda di Kenagarian Gunuang Rajo menggunakan kata sapiradan yang merujuk pada makna 'kesemutan'. Sementara penutur tua dahulunya menggunakan kata ngarijan. Kata ini dituturkan saat seseorang merasakan kesemutan pada tubuh mereka. Perbedaan itu terjadi karena adanya faktor eksternal segi kemasyarakatan, yakni penutur asli KGR yang mempunyai kebiasaan memakai kata sapiradan. Sekarang kata ngarijan mereka gunakan sebagai olok-olokan. Penutur tua pun ikut memilih kata sapiradan. Masing-masing kata itu bersinonim sehingga frekuensi penggunaannya sangat mempengaruhi ketahanan pemakaian kata tersebut.

Penutur muda

: Tolongan nasi dalam kudai ayah ciek, Nak!

: Tolong nasi dalam tas ayah satu, Nak!

: 'Tolong ambilkan nasi dalam tas ayah, Nak!'

Penutur tua

: Tolongan nasi dalam gaduik ayah ciek, Nak!

: Tolong nasi dalam tas ayah satu, Nak!

: 'Tolong ambilkan nasi dalam tas ayah, Nak!'

Pada data di atas terlihat jelas perbedaan penggunaan kata antara penutur muda dan penutur tua. Penutur tua menggunakan kata gaduik dan penutur muda menggunakan kata kudai. Gaduik dan kudai adalah dua buah kata yang memiliki makna yang sama, yaitu tas. Saat penulis menanyakan kepada penutur muda apa itu gaduik, mereka sama sekali tidak mengetahui istilah tersebut. Namun, ketika penulis tanya apa itu kata kudai, mereka mengetahuinya. Lalu, penulis melakukan wawancara kepada penutur tua dan menanyakan kata kudai, mereka mengetahuinya tetapi, mereka dahulu menggunakan kata gaduik.

Penyebab hilangnya kata gaduik dan digantikan oleh kata kudai selain dari faktor dari masyarakatnya, ada juga faktor dari bahasa asing dan juga karena benda dari kata pertama itu sudah tidak digunakan lagi. Gaduik terbuat dari daun ilalang yang dikeringkan lalu dianyam hingga berbentuk tas. Sekarang sudah tidak ditemukan benda itu lagi. Saat ini yang banyak ditemukan adalah benda berupa tas yang terbuat dari benang wol. Ini salah 


\section{Jurnal Elektronik WACANA ETNIK - Vol 6 No 2 Oktober 2017, (97 - 110) \\ p ISSN 2089-8746, e ISSN 2302-7142}

satu faktor yang menyebabkan kata gaduik hilang dan kemudian lebih sering menggunakan kata kudai. Selain itu, juga ada pengaruh dari segi kemasyarakatannya yang sering menggunakan kata-kata baru.

Hal ini menunjukkan gejala kematian bahasa. Ada dua jenis kematian bahasa, yaitu (1) bunuh diri bahasa (language suicide) dan (2) pembunuhan bahasa (language murder). Lebih lanjut dikatakan bahwa bunuh diri bahasa terjadi karena suatu bahasa meminjam banyak sekali kosakata asing sehingga bahasa tersebut berubah wujud secara keseluruhan (bahasa Tok Pisin di Papua New Guinea, yang meminjam sangat banyak kosakata bahasa Inggris Australia). Pembunuhan bahasa menyangkut kematian yang terjadi karena bahasa itu didesak oleh bahasa lain yang lebih dominan, baik secara sosio-budaya, politik, maupun ekonomi (bahasa imigran Eropa di Amerika Serikat terdesak oleh bahasa Inggris Amerika). Di samping itu, dapat pula terjadi karena penutur bahasa itu punah atau dipunahkan (bahasa Indian di AS dan Meksiko serta bahasa Aborigin di Australia) (Sobarna, 2007; Tampubolon, 1999).

\section{MUNCULNYA KATA BARU}

Setelah dilakukan setelah klasifikasi dan analisis data, penulis menemukan adanya kata-kata baru yang terdapat pada kosa kata bahasa Minangkabau oleh penutur tua dan penutur muda Gunuang Rajo, Kecamatan Batipuah, Kabupaten Tanah Datar.

Penutur muda

: Ihsan, toloang ambiak-an bola adiak ciek, Nak!

: Ihsan, tolong ambilkan bola adik satu, Nak!

: 'Ihsan, tolong ambilkan bola adik, Nak!'

Penutur tua

: Ihsan, toloang ambiak-an imban adiak ciek, Nak!

: Ihsan, tolong ambilkan bola adik satu, Nak!

: 'Ihsan, tolong ambilkan bola adik, Nak!'

Pada data di atas terdapat dua kosa kata yang memiliki makna sama. Dua bentuk ini pada dasarnya merupakan bentuk yang mengalami perubahan. Kata imban merupakan bentuk awal yang digunakan oleh masyarakat, sementara bentuk kedua menggunakan kata bola. Kata bola adalah kosa kata bahasa Indonesia. Kata ini lebih sering dipakai dalam percakapan sehari-hari dibandingkan dengan kata lama BMPTPM di Kenagarian Gunuang Rajo, yakni kata imban. Artinya adanya pengaruh bahasa lain terhadap perkembangan kosa kata penutur muda. Hal ini disebabkan oleh lembaga pendidikan di tempat mereka bersekolah. Bahasa yang digunakan sebagai alat komunikasi dengan pengajar adalah bahasa Indonesia, sehingga mau tidak mau ataupun sadar tidak sadar kosa kata penutur muda KGR yang bersekolah terpengaruh oleh kosa kata bahasa Indonesia tersebut.

Selanjutnya, penyebab lainnya kata imban tidak ada lagi saat ini. Imban orang zaman dahulu terbuat dari daun kelapa atau kulit daun bayur yang masih muda yang digulung dan dilekatkan dengan getah yang dibuat secara manual dan menggunakan waktu yang lama untuk membuatnya serta jarang ada di pasaran. Sementara bola sekarang ini sudah punya pabrik yang canggih dan mudah didapatkan di pasaran. Jarangnya penggunaan kata imban mengakibatkan kata imban berpotensi hilang dengan sendirinya. Kata ini hanya akan dituturkan oleh penutur tua dalam kondisi tertentu, misalnya saat penulis melakukan wawancara pada penutur tua. 
Penutur muda

: Urang dulu kalau ka pasa jalan kaki sajonyo

: Orang dahulu jika ke pasar jalan kaki saja.

: 'Orang dahulu jika pergi ke pasar jalan kaki saja'

Penutur tua

: Urang inangko kalau ka pasa jalan kaki sajonyo

: Orang dahulu jika ke pasar jalan kaki saja.

: 'Orang dahulu jika pergi ke pasar jalan kaki saja'

Penutur muda menggunakan kata $d u l u$, sedangkan penutur tua menggunakan kata inangko. Itu terjadi karena kelatahan masyarakat penutur BMPTPM di Kenagarian Gunuang Rajo lebih sering menggunakan kata bahasa Indonesia saat sekarang ini. Penutur muda juga terpengaruh oleh lingkungannya. Lingkungan sangat besar pengaruhnya terhadap perkembangan kosa kata penutur muda seperti terpengaruh oleh kebiasaan orang-orang sekitar yang memakai kata tertentu. Misalnya, perantau (keturunan Gunuang Rajo) dari Jakarta pulang dengan membawa bahasa yang sudah terpengaruh bahasa Indonesia. Selain itu, kebiasaan masyarakat memilih kata yang dipakai, membuat sebagian kata yang ditinggalkan menjadi hilang.

\section{Penutur muda \\ : Dompek iniak tu cabiak a. \\ : Dompet nenek itu robek KF. \\ : 'Dompet nenek itu robek' \\ Penutur tua \\ : Kincik iniak tu cabiak a. \\ : Dompet nenek itu robek KF. \\ : 'Dompet nenek itu robek'}

Penutur muda menggunakan kata dompek, sedangkan penutur tua selain menggunakan kata dompek. Mereka dahulu juga menggunakan kata kincik. Dompek dan kincik memiliki makna yang sama, yaitu dompet tempat meletakan atau menyimpan uang, kartu, dan sejenis lainnya. Dompe merupakan kata bahasa Indonesia. Kata kincik sudah sangat jarang digunakan oleh penutur muda. Akibatnya kata ini menjadi kata yang berfrekuensi rendah.

Pada data ini, faktor penyebab hilangnya kata lama disebabkan oleh tingginya frekuensi pemakaian kata dompek, sehingga menyebabkan kata kincik tidak lagi digunakan oleh masyarakat Gunuang Rajo pada saat ini. Kebiasaan masyarakat memilih kata yang dipakai, membuat sebagian kata yang ditinggalkan menjadi hilang atau tidak digunakan lagi. Jika hal ini terus dibiarkan generasi selajutnya tidak akan mengetahuilagi kosa kata asli Gunuang rajo.

Penutur muda

: Samo jo acek, lah kanyang paruik makannyo nyo pai lai

: Sama dengan pacat, sudah kenyang perut makannya pergi lagi

: 'Sama dengan Pacet kalau sudah kenyang pergi lagi'

Penutur tua

: Samo jo acek, lah gandik paruik makannyo nyo pai lai

: Sama dengan pacet, sudah kenyang perut makannya pergi lagi

: 'Sama dengan pacet kalau sudah kenyang pergi lagi'

Kata gandik oleh penutur muda sudah tidak digunakan lagi dalam percakapan sehari-hari. Penutur muda saat ini menggunakan kata kanyang yang merujuk pada makna 'kenyang'. Gandik digunakan oleh penutut tua 
dahulu saat mereka sudah merasa 'kenyang'. Sementara penutur muda sekarang menggunakan kanyang untuk mengungkapkan rasa kenyang.

Hal yang menyebabkan kata gandik hilang adalah dominannya pemakaian kata kanyang digunakan. Karena sekarang kata gandik lebih sering diucapkan untuk binatang. Itu pun yang sering mengucapkannya hanya penutur tua. Akhirnya, kata gandik sudah jarang digunakan. Oleh sebab itu, penutur yang berusia 30 tahun ke bawah tidak lagi menggunakan kata gandik untuk sebutan kanyang yang merujuk makna pada 'kenyang'.

Penutur muda

: Amak ka pasa tadi.

: Ibu ke pasar tadi.

: 'Ibu pergi ke pasar tadi'

Penutur tua

: Amak ka mudiak tadi.

: Ibu ke pasar tadi.

: 'Ibu pergi ke pasar tadi'

Frekuensi penggunaan kata mudiak mengalami penurunan penggunaan. Akibatnya, kata ini didominasi oleh kata pasa yang lebih sering digunakan oleh penutur muda KGR. Penutur muda menggunakan pasa yang merujuk pada makna 'pasar'. Sedangkan penutur tua menggunakan kata mudiak yang merujuk pada makna 'pasar'. Pasa adalah tempat orang berkumpul dari berbagai daerah dan juga berbagai ras untuk melakukan jual beli barang. Seiring berkembangnya zaman, kata mudiak sudah tidak digunakan lagi oleh masyarakat di Kenagarian Gunuang Rajo.

Faktor penyebab kata mudiak tidak digunakan lagi ialah adanya sebagian masyarakat di Kenagarian Gunuang Rajo yang pergi merantau. Ketika di perantauan, mereka mengatakan tempat berbelanja itu dengan kata 'pasar'. Ketika mereka pulang ke kampung halaman, kata 'pasar' masih mereka gunakan. Akan tetapi, dia mengubah sedikit cara pengucapannya dengan kata pasa. Lama kelamaan, masyarakat di Kenagarian Gunuang Rajo mulai terbiasa menggunakan kata pasa. Akhirnya, kata mudiak pun mulai jarang digunakan dan lama kelamaan mulai menghilang dengan sendirinya.

Penutur muda

: Tolong ambiakan kukuran tu ciek a!

: Tolong ambilkan kukuran itu KF!

: 'Tolong ambilkan kukuran itu!'

Penutur tua

: Tolong ambiakan tungkahan tu ciek a!

: Tolong ambilkan kukuran itu KF!

: 'Tolong ambilkan kukuran itu!'

Penggunaan kata tungkahan oleh penutur tua sudah jarang digunakan. Namun, sebagian dari penutur tua adakalanya sesekali (seperti saat penulis melakukan wawancara) memakai kata tungkahan. Kata tungkahan oleh penutur tua dimaknai dengan alat untuk memarut kelapa, sedangkan penutur muda menggunakan kata kukuran. Saat ini, tungkahan sudah jarang digunakan. Hal ini dikarenakan tungkahan menggunakan tenaga manusia sehingga butuh waktu yang lama untuk memarut kelapa. Sementara kukuran sekarang, tidak seutuhnya menggunakan tenaga manusia. Akan tetapi, menggunakan mesin untuk menggerakkan alatnya. 


\section{Jurnal Elektronik WACANA ETNIK - Vol 6 No 2 Oktober 2017, (97 - 110) \\ p ISSN 2089-8746, e ISSN 2302-7142}

Selain alat yang digunakan sudah jarang digunakan, adanya kebiasaan masyarakat yang memilih pemakaian suatu kata dalam percakapan sehari-hari juga menjadi faktor penyebab terjadinya perubahan dan hilangnya kata tersebut. Perubahan dan perkembangan bahasa merupakan dampak dari perubahan dan perkembangan sosial budaya masyarakat. Hal ini secara dinamis akan terus terjadi karena tuntutan kehidupan terus mendorong masyarakat untuk berusaha memenuhi kebutuhan hidupnya sehari-hari. Kedinamisan dalam perubahan ini menyebabkan terjadinya perbedaan bahasa yang digunakan oleh masyarakat generasi tua dengan bahasa yang digunakan masyarakat generasi muda. Dalam banyak bahasa yang ada di dunia, perbedaan usia sering menimbulkan perbedaan bahasa karena bahasa menjadi wahana utama dalam memenuhi tuntutan kehidupan manusia untuk menyampaikan ekspresi tentang dunia, yakni wawasan tentang dunia sekitar (Sartini, 2014; Suyitno, 2008).

\section{PENUTUP}

Kata-kata yang hilang dan tidak dipakai lagi dalam kosa kata bahasa Miinangkabau di Kenagarian Gunuang Rajo disebabkan oleh faktor internal dan faktor eksternal. Faktor internal yang menyebabkan terjadinya perubahan penggunaan kosa kata adalah pertentangan homonimis. Faktor eksternal yang menyebabkan terjadinya perubahan penggunaan kosa kata adalah sejarah, segi kemasyarakatannya, usia, pendidikan, juga pengaruh bahasa asing, dan pendatang yang masuk ke daerah tersebut. Kata-kata yang hilang cenderung diikuti oleh gejala timbulnya kata baru yang menggantikan kata tersebut. Munculnya kata-kata baru pada kosa kata bahasa Miinangkabau di Kenagarian Gunuang Rajo dibentuk dari luar bahasa bahasa Miinangkabau di Kenagarian Gunuang Rajo.

Perubahan penggunaan yang terjadi pada sebagian kosa kata bahasa Minangkabau oleh penutur tua dan penutur muda di Kenagarian Gunuang Rajo, Kecamatan Batipuah, Kabupaten Tanah Datar sangat dipengaruhi oleh faktor usia. Generasi tua masyarakat Gunuang Rajo masih mengetahui kata-kata lama yang mengalami perubahan penggunaan. Namun, mereka juga memakai atau mencontoh kata yang dipakai oleh penutur usia muda. Ini terjadi karena penutur tua berusaha mengimbangi dan menyesuaikan diri dengan penutur usia muda dan juga kelatahan mereka mengikuti kata-kata yang mereka dengar. Faktor pendidikan juga ikut mempengaruhi terjadinya perubahan penggunaan kosa kata antara penutur muda dan penutur tua. Bahasa yang dipakai dalam pendidikan menggunakan bahasa Indonesia. Selain itu, merantau juga ikut mempengaruhi perubahan kosa kata bahasa Miinangkabau di Kenagarian Gunuang Rajo. Saat mereka kembali ke kampung halaman, bahasa mereka sedikit berubah dan lebih cenderung berupa bentuk bahasa tempat mereka merantau atau juga bahasa Indonesia. Lamakelamaan masyarakatnya mulai terbiasa mengikuti kata baru yang diucapkan oleh anak yang berpendidikan dan mengakibatkan kata lama mereka jadi tinggal dan lama kelamaan mulai menghilang dengan sendirinya seiring berputarnya waktu.

\section{DAFTAR PUSTAKA}

Chaer, A. (2003). Linguistik Umum. Jakarta: Rineka Cipta.

Chaer, A. (2010). Sosiolinguistik Perkenalan Awal. Jakarta: Rineka Cipta.

Khasanah, I., Laksmita, D., Tilman, R. D. C., \& Rizky, R. (2015). Fenomena Penggunaan Bahsa Asing dalam Penamaan Bisnis Kuliner di Kawasan Soekarno Hatta Kota Malang. Jurnal Lingkar Widyaiswara, 2(1), 111. Retrieved from http://juliwi.com/published/E0201/Paper0201_01-11.pdf 
Kridalaksana, H. (2008). Kamus Linguistik. Jakarta: Gramedia.

Sartini, N. W. (2014). Revitalisasi bahasa Indonesia dalam konteks kebahasaan. Masyarakat, Kebudayaan Dan Politik, 27(4), 206-210. https://doi.org/10.20473/MKP.V27I42014.206-210

Sobarna, C. (2007). BAHASA SUNDA SUDAH DI AMBANG PINTU KEMATIANKAH ? Makara, Sosial Humaniora, 11(1), 13-17.

Suyitno, I. (2008). KOSAKATA LAGU DAERAH BANYUWANGI : KAJIAN ETNOLINGUISTIK ETNIK USING. Humaniora, 20(2).

Tampubolon, D. P. (1999). Gejala-gejala Kematian Bahasa: Suatu Observasi Ragam Politik Orde Baru. In S. Dardjowidjojo \& Y. Nasanius (Eds.), PELLBA 12. Jakarta: Kanisius.

Usman, A. H. (1979). Pengantar Ilmu Kosa Kata (Leksikologi). Padang: FPBS-IKIP. 